\title{
Functional capacity and sociodemographic conditions of elderly people at the Eliza Queiroz Maciel Living Center of Manacapuru, Amazonas, Brazil
}

\section{Summary}

Goals: To evaluate the functional capacity and sociodemographic conditions of the elderly people who were attended at the Eliza Queiroz Maciel Living Center in the city of Manacapuru, Amazonas, Brazil with emphasis on functional capacity.

Methods: descriptive cross-sectional research study approach.

Results: Among the 78 elderly people participants, women (83.3\%), widows $(41.0 \%)$, and between $65-69$ years old $(37.2 \%)$, brown $(46.1 \%)$, Catholic $(76.9 \%)$, incomplete elementary school $(35.9 \%)$, 4 to 6 children $(30.8 \%)$, retired $(78.2 \%)$, monthly income 1 to 3 minimum wages $(73.1 \%)$, house of masonry $(75.6 \%)$ and own house $(88.5 \%)$, with electricity, piped water, garbage collection and sewage services $(48.7 \%)$. They had, in average, dependence in the Katz ADLs (5.1\%) and Lawton-Brody IADLs scales(16.7\%).

Conclusions: It is concluded that this elderly people study constitutes an important tool for the manager of the Eliza Queiroz Maciel Living Center, in the work of prevention of aggravations to the health of the elderly people who participate in these activities aiming at improving the quality of life.

Keywords: disability evaluation, functioning aging, gerontology, functional capacity, elderly people health
Volume 3 Issue 6 - 2019

\author{
Hurtado-Guerrero Ana Felisa,' Elizama \\ André Gomes Lopes, ${ }^{2}$ José Camilo Hurtado- \\ Guerrero $^{3}$ \\ 'PhD in Public Health, Escola de Saúde Pública, Escola de \\ Ciências da Saúde da Universidade do Estado do Amazonas - \\ UEA, Brasil \\ ${ }^{2}$ Nursing of Secretaria Estadual de Saúde no Município de \\ Manacapuru, Bachelor in nursing, Universidade do Estado do \\ Amazonas - UEA, Brasil \\ ${ }^{3}$ Post-Doc in Animal behavior (University of Alberta). PhD \\ in Biological Sciences (Entomology) INPA-UFAM, IBEF - \\ Universidade Federal do Oeste do Pará - UFOPA, Brasi
}

Correspondence: José Camilo Hurtado-Guerrero, Universidade Federal do Oeste do Pará - UFOPA, Instituto de Biodiversidade e Florestas - IBEF, Rua Vera Paz, s/n, Salé, Santarém, PA, Brasil, CEP: 68040-470. Tel (93) 999780202, e-mail jhocamhur@gmail.com

Received: October 28, 2019 | Published: November 06, 2019

\begin{abstract}
Abbreviations: ADLs, activities of daily life; IADLs, instrumental activities of daily life; UEA, universidade do estado do amazonas; TCLE, termo de consentimento livre e esclarecido (free and informed consent form); AM, amazonas; SC, santa catarina; IBGE, instituto brasileiro de geografia e estatística; PNAD, pesquisa nacional por amostra de domicílio; $\mathrm{CE}$, ceará; $\mathrm{BA}$, bahia; $\mathrm{CEP}$, comitê de ética em pesquisa (research ethics committee); CAIMI, center for integral care of the elderly people
\end{abstract}

\section{Introduction}

Brazil, during the 21 st century, will be one of the four countries with the fastest aging world population, occupying the sixth place in the world ranking in number of elderly in 2025 and rising from $7.4 \%$ in 2013 to a proportion above $35.0 \%$ in 2070 , even higher than that presented by the group of developing countries. ${ }^{1,2}$ The elderly people are an age group that presents great demand for health services and in this context their evaluation should include not only the diagnosis of physical and mental diseases, but also an understanding of the functional aspects, especially the socioeconomic conditions and selfcare capacity, which will reveal the degree of functional independence of the elderly people. ${ }^{3}$ The assessment of functional capacity becomes, therefore, essential for the choice of the best type of intervention and monitoring of the clinical and functional status of the elderly people. ${ }^{4}$ Functional capacity is defined as the independence for the performance of activities of daily living involving physical, mental and social skills, valuing the autonomy and self- determination of the elderly individual. ${ }^{5}$ And functional disability refers to the difficulty or need for help for the individual to perform tasks in their daily lives. ${ }^{6}$
The maintenance of functional capacity is closely related to the autonomy and physical and mental independence of the elderly people. The commitment to perform any item of the ADLs and IADLs can affect the maintenance of their functional capacity, impairing autonomy and independence, and can influence their health. ${ }^{7}$ Thus, when the functional capacity of the elderly people is compromised to the point of preventing the individual from taking care of himself, the burden on the family and on the health system can be very great. ${ }^{8}$ Autonomy is understood here as the ability to perform their daily activities independently and satisfactorily, while independence means the ability to perform activities of daily living without help. ${ }^{9}$ Thus, if people grow old with their autonomy and independence preserved the difficulties will be less for them, their family and society, because with the ability to perform any activity when they want to live independently and autonomously, exercising their rights and duties as citizens. ${ }^{9}$

As mentioned, ${ }^{10}$ functional capacity has been considered an indicator of the health-disease process, since chronic diseases and functional disabilities in the elderly population have been more difficult to prevent than even avoid deaths in the elderly people. Functional disabilities also increase the risk of hospitalization, long-term care needs and increase the costs for health services. The functional capacity of the elderly, especially with regard to the motor dimension, is one of the main indicators of successful aging, quality of life and well-being. ${ }^{11}$ Thus, investigating health-related quality of life in its multidimensionality allows identifying the main aspects related to the health-disease process, since health status is closely linked to quality of life and is influenced by the presence of disabilities in the 
individual. ${ }^{12}$ In this sense, this study aimed to evaluate the functional capacity and sociodemographic conditions of elderly people at the Eliza Queiroz Maciel Living Center in Manacapuru, Amazonas, Brazil seeking to provide information on their quality of life and guide policies for a successful aging, since it is the responsibility of health policies to contribute to more people reaching advanced ages with the best possible health status.

\section{Methods}

This was a descriptive cross-sectional research study approach. with analysis of primary data, conducted with 78 elderly people who were attended at the Eliza Queiroz Maciel Living Center of Manacapuru in the state of Amazonas. The data collection occurred in the period from August 2010 to December 2011. In order to know the sociodemographic characteristics, a questionnaire was prepared and applied through an interview at the study site, in a reserved place, on the days of group activities, before or after the activities, following the recommendations of Gil. ${ }^{13}$ In order to cover as many subjects as possible, it was necessary to make house visits with the elderly people who were absent, i.e., those who participate in the activities, but were not always present at the site for some reason. In the evaluation of functional capacity, widely known instruments were used in national and international gerontological studies, such as the ADL Scale of Katz ${ }^{14}$ to measure the Activities of Daily Living (ADLs), and the IAVD scale of Lawton-Brody, ${ }_{15}^{15}$ to measure the Instrumental Activities of Daily Living (IADLs)

The evaluation of the ADLs focuses on the performance of 06 self-care functions, classifying the elderly person as independent, partially dependent and totally dependent for certain activities. In the evaluation of IADLs, which evaluates the elderly people in their capacity for social interaction and indicates whether they are able to live independently in their community, the elderly people were classified as independent, partially dependent or totally dependent in the performance of nine functions. ${ }^{16}$ Data analysis used absolute and relative frequency measurements. The organization of the database was in Microsoft Office Excel, version 2010, and the analysis of variables in software Minitab v.14, SPSS v. 20 and Epi Info v.6. This work had the appreciation of the Research Ethics Committee of the University of the State of Amazonas (UEA), according to opinion $\mathrm{n}^{0}$ 003/11-CEP/UEA on 25.02.2011. All participants authorized their participation by signing or dactyloscopying printing of the Termo de Consentimento Livre e Esclarecido (TCLE) (Free and Informed Consent Form), in compliance with Resolution 196/96 of the National Health Council on research involving human beings.

\section{Results}

Aspects related to socio demographic and economic factors, housing conditions and functional capacity of 78 elderly people were investigated, which is equivalent to $100 \%$ of those being attended in the Eliza Queiroz Maciel Living Center of Manacapuru in the state of Amazonas, Brazil. Table 1 shows the predominance of elderly women $(83.3 \%)$ and low elderly men participation $(16.7 \%)$. The distribution of the several age groups revealed that $37.2 \%$ were between 65 and 69 years old. In relation to schooling, it was verified that incomplete elementary education predominated $(35.9 \%)$, followed by the illiterate group (25.6\%). When the race/colour category was analyzed, there was a predominance of those who declared themselves as brown (46.2\%), followed by those who declared themselves white $(44.9 \%)$.
In what refers to the naturalness, the majority was natural of other cities of Amazonas (47.4\%), the born in Manacapuru reached a percentage of $42.3 \%$, followed by only $10.3 \%$ of naturalness of other States of the North Region. In marital status, it was found that the majority were widowers $(41.0 \%)$, followed by $29.5 \%$ of married couples. Regarding religion, $76.9 \%$ were Catholic and had 4 to 6 children (30.8\%). Regarding occupation, it was observed that $78.2 \%$ were retired, followed by occupation at house (11.5\%). Respecting the monthly income, it was noticed that $73.8 \%$ received income of 1 to 3 minimum wages, generally, coming from retirement and pension. In relation to the type of habitation, the majority lived in houses of masonry (75.6\%), they had their own houses (88.5\%), and had access to all basic sanitation services (48.7\%) (Table 2).

Table I Distribution according to the socio-demographic aspects of the elderly people who were attended at the Eliza Queiroz Maciel Living Center of Manacapuru - Amazonas, Brazil - 20II

\begin{tabular}{|c|c|c|}
\hline Variables & $\mathbf{n}$ & $\%$ \\
\hline \multicolumn{3}{|l|}{ Sex } \\
\hline Men & 13 & 16.7 \\
\hline Women & 65 & 83.3 \\
\hline \multicolumn{3}{|l|}{ Marital status } \\
\hline Single & 3 & 3.8 \\
\hline Married & 23 & 29.5 \\
\hline Widower & 32 & 41.0 \\
\hline Separate & 13 & 16.7 \\
\hline Other & 7 & 9.0 \\
\hline \multicolumn{3}{|l|}{ Age Group } \\
\hline $60-64$ & 21 & 26.9 \\
\hline $65-69$ & 29 & 37.2 \\
\hline $70-74$ & 21 & 26.9 \\
\hline 75 or + & 7 & 9.0 \\
\hline \multicolumn{3}{|l|}{ Race/Color } \\
\hline White & 35 & 44.9 \\
\hline Black & 5 & 6.4 \\
\hline Indigenous & 2 & 2,6 \\
\hline Yellow & 0 & 0,0 \\
\hline Brown & 36 & 46.2 \\
\hline \multicolumn{3}{|l|}{ Place of birth } \\
\hline Manacapuru (Amazonas) & 33 & 42.3 \\
\hline Other Amazonas Municipalities & 37 & 47.4 \\
\hline Other States & 8 & 10.3 \\
\hline \multicolumn{3}{|l|}{ Religion } \\
\hline Catholic & 60 & 76.9 \\
\hline Evangelical & 18 & 23.1 \\
\hline
\end{tabular}




\begin{tabular}{lcc} 
Table continued & $\mathbf{n}$ & $\%$ \\
\hline Variables & & \\
\hline Education & 20 & 25.6 \\
Illiterate & 13 & 16.7 \\
Read and write a note & 28 & 35.9 \\
Incomplete elementary education & 5 & 6.4 \\
Complete elementary school & 1 & 1.3 \\
Incomplete high school & 9 & 11.5 \\
High school complete & 1 & 1.3 \\
Incomplete higher education & 1 & 1.3 \\
Complete higher education & & \\
Children & 15 & 19.2 \\
$0-3$ & 24 & 30.8 \\
$4-6$ & 18 & 23.1 \\
$7-9$ & 21 & 26.9 \\
\hline 10 or + & &
\end{tabular}

Source: authors; $\mathbf{n}$, sample size; \%, percentage

Table 2 Distribution according to economic aspects and housing conditions of the elderly people who were attended at the Eliza Queiroz Maciel Living Center of Manacapuru - Amazonas, Brazil - 20II

\begin{tabular}{|c|c|c|}
\hline Variables & $\mathbf{n}$ & $\%$ \\
\hline \multicolumn{3}{|l|}{ Occupation } \\
\hline Retired & 61 & 78.2 \\
\hline From House & 9 & 11.5 \\
\hline Other & 8 & 10.3 \\
\hline \multicolumn{3}{|l|}{ Monthly income } \\
\hline No income & 2 & 2.6 \\
\hline$<$ of a minimum wage & 10 & 12.8 \\
\hline From I to 3 minimum wages & 57 & 73.1 \\
\hline 4 or + minimum wages & 9 & 11.5 \\
\hline \multicolumn{3}{|l|}{ Type of housing } \\
\hline Masonry house & 59 & 75.6 \\
\hline Wooden House & 12 & 15.4 \\
\hline Mixed House & 7 & 9.0 \\
\hline \multicolumn{3}{|l|}{ House } \\
\hline House Own & 69 & 88.5 \\
\hline Family members' own & 4 & 5.1 \\
\hline Rented & 4 & 5.1 \\
\hline Other & I & 1.3 \\
\hline
\end{tabular}

\begin{tabular}{|c|c|c|}
\hline Variables & $\mathbf{n}$ & $\%$ \\
\hline \multicolumn{3}{|l|}{ Basic sanitation } \\
\hline Piped water, electricity and waste collection & 5 & 6.4 \\
\hline $\begin{array}{l}\text { Piped water, electricity, garbage collection and } \\
\text { connection to the sewerage network }\end{array}$ & 35 & 44.9 \\
\hline $\begin{array}{l}\text { Piped water, electricity, garbage collection, } \\
\text { connection to the sewage network and } \\
\text { telephone }\end{array}$ & 38 & 48.7 \\
\hline
\end{tabular}

Functional capacity comprises two groups of activities, namely: Activities of Daily Life (ADLs) and Instrumental Activities of Daily Life (IADLs). Figure 1 shows the six functions used to evaluate these Activities of Daily Living (ADLs). Of these, the one that most affected the elderly people was the general urinary incontinence $(28.2 \%)$ and the specific one: for men $(0.0 \%)$ and women $(33.8 \%)$, but in the other activities there was not an important percentage that caused dependence in the majority. Figure 2 shows that in the Instrumental Activities of Daily Living (IADLs), the elderly people presented greater dependence when they used the telephone (29.5\%), followed by help to travel to distant places and perform domestic manual work, both with the same percentage of $19.2 \%$, and take the medication in the right dose and time $(17.9 \%)$. Although the IADLs that performed with greater independence were: financial care $(94.9 \%)$ and shopping $(91.0 \%)$.

\section{Discussion}

This study allowed evaluating the functional capacity and sociodemographic conditions of the elderly people at the Eliza Queiroz Eliza Queiroz Maciel Living Center of Manacapuru, Amazonas. The research showed a predominance of elderly women, coinciding with the findings in other studies in the city of Manaus ${ }^{17,18}$ and other regions of the country. ${ }^{19,20}$ There are some factors that may explain the higher elderly women participation in studies, such as women live longer, because they are usually lonely, and less exposed to certain risk factors and show greater concern with their health-seeking more health services, especially for the prevention of diseases. ${ }^{19}$ Due to the lower mortality among women, they predominate in the elderly population, constituting most of the longevity population..$^{21}$ Women and men live and age differently and, even though old age is not universally feminine, it has a strong gender component. ${ }^{21}$ While in the year 2000, for every 100 elderly women there were 81 elderly men, it is estimated that in 2050 there will be about 76 elderly women for every 100 elderly women..$^{22}$ The greater participation of elderly women in this type of activity can also be observed due to their greater interest and capacity to adapt to the new challenges that ageing brings, such as: search for leisure activities, company, distraction, health prevention practices, especially for the improvement of their quality of life. ${ }^{22}$

In the analysis of ageing by age group, it was perceived greater participation of the elderly between 65 and 69 years. Similar findings were found in the study of Hurtado - Guerrero, Alencar and Hurtado Guerrero, ${ }^{23}$ studying elderly people in the 60 to 69 age group of Nova Olinda do Norte in the state of Amazonas (83.3\%) and Mazo et al. ${ }^{24}$ obtained relevant results in this age group of elderly people registered in the Centers for Coexistence of the Elderly People in the city of São José (SC). The age group composed of people over 65 years old increased from 3.5 in 1970 to $5.5 \%$ in 2000 , and by 2050 this age group should reach $19 \%$ of the Brazilian population, which will lead 
to a drastic change in the pattern of the Brazilian population pyramid. ${ }^{22}$ The increase in the population over 60 years of age is largely due to the increase in life expectancy, since today we live longer, although in the midst of social, economic and health differences..$^{25}$

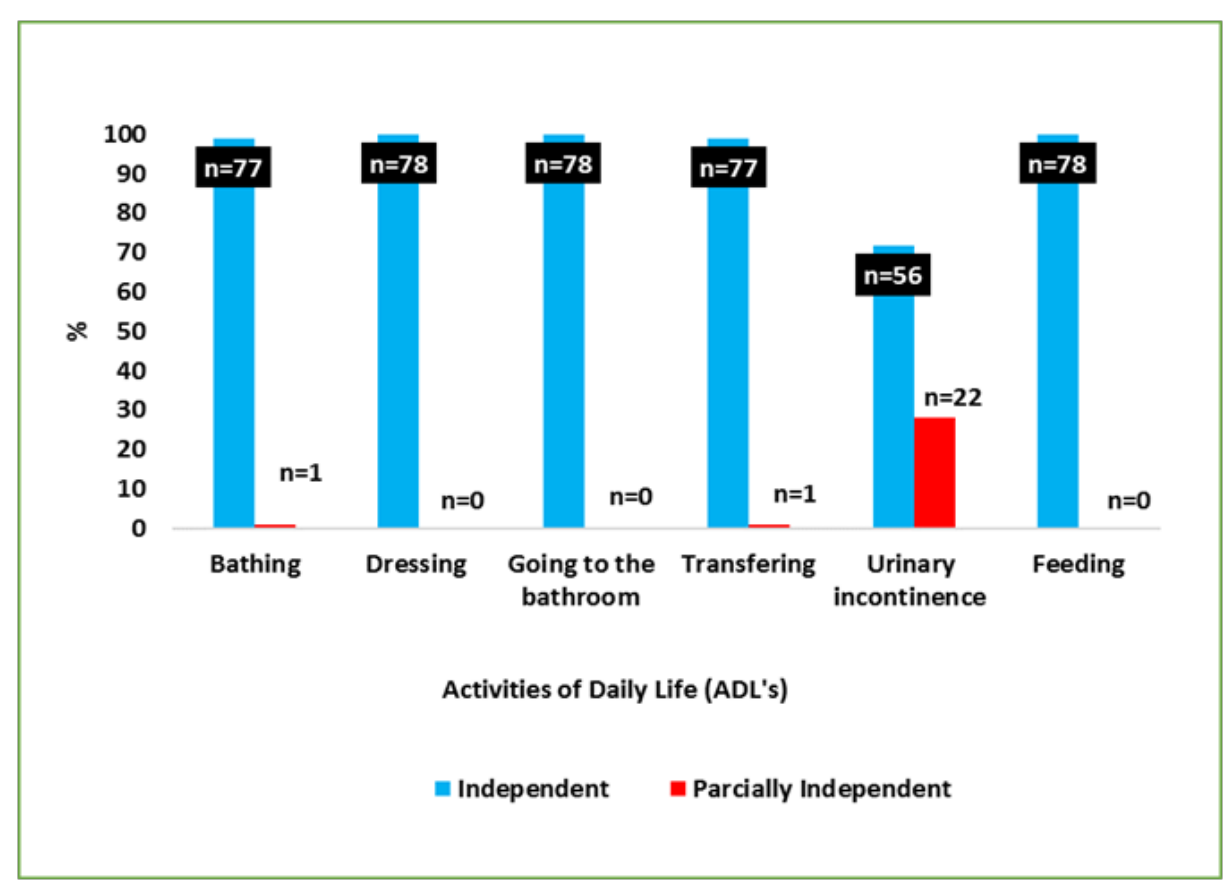

Figure I Percentage of functional capacity to perform Activities of Daily life (ADLs) of the elderly people who were attended at the Eliza Queiroz Maciel Living Center of Manacapuru - Amazonas, Brazil - $20 \mathrm{I}$ I.

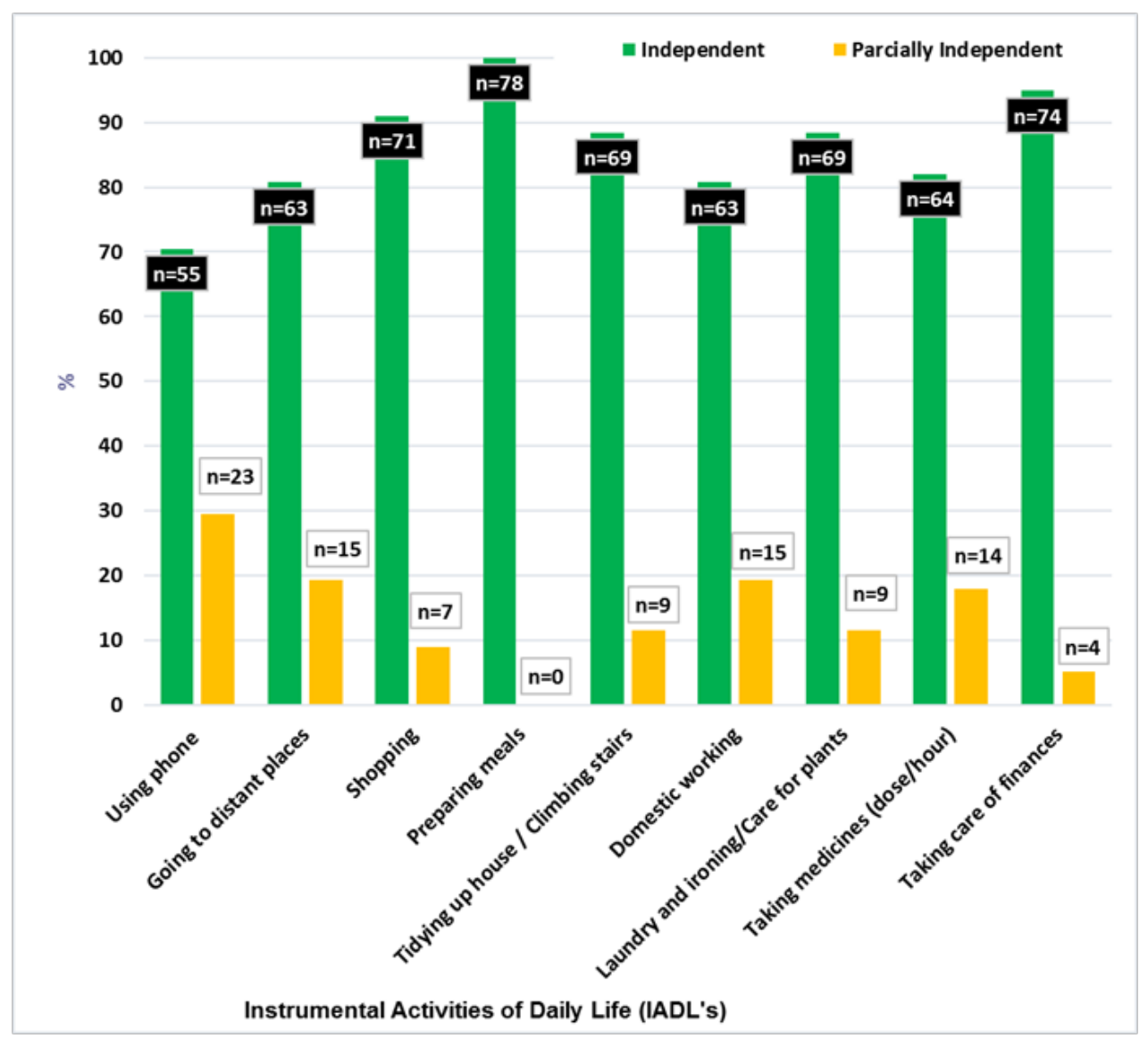

Figure 2 Distribution according to the functional capacity to perform the Instrumental Activities of Daily Life (IADLs) of the elderly people who were attended at the Eliza Queiroz Maciel Living Center of Manacapuru - Amazonas, Brazil - 201 I. 
It was verified that the majority of the elderly people had incomplete primary education $(35.9 \%)$, followed by illiteracy $(25.6 \%)$. The findings of this study are in line with the results of the study by Chaves ${ }^{17}$ and Bonifácio ${ }^{18}$ in Manaus, that pointed out similar results. Some factors may favour this condition in Amazonas, as the difficulty of access to schools, housing in remote locations of the forest, combined with household chores and caring for children and grandchildren. The low level of education of the elderly people is possibly a reflection of the social organization of the beginning of the last century that hindered access to school by the poorest and women, since at that time there was not as much demand for education as today, and the role of women in society was restricted to marriage, having children and dedication to care for the house and without any stimulus for other studies. ${ }^{26,27}$

Thus, illiteracy can be considered an important limiting factor for survival and quality of life insofar as it reflects one of the aspects of social inequalities in the country. However, we are currently experiencing days of overcoming them, since many women are increasingly entering the school environment and are looking for a professional career in the fight for equal rights. Elderly women are becoming literate, attending schools and even universities. Everything indicates that in the next generations the level of education will improve for this segment of the population due to easier access to schools and the competitiveness of the labour market. It was observed in this study a high frequency of self-declared elderly brown (46.2\%), followed by white $(44.9 \%)$. These results can be confirmed in other studies such as Portela $^{28}(82.6 \%)$ and Souza and Silver ${ }^{29}(48.0 \%)$. According to IBGE data in $2010,{ }^{30}$ the proportion of elderly Brazilians who declared themselves white $(56.8 \%)$, increasing brown $(33.8 \%)$ and black (7.7\%), and among the large regions of Brazil, the Northern Region has the highest number of brown (71.2\%), with the Amazon the state with the highest percentage of brown with $77.2 \%$ of the population. A study by Oliveira et al. ${ }^{31}$ which analyzed the PNAD data (2008), found that the race/brown colour was positively associated with worse self-reported health status and the black colour with the highest number of chronic diseases, as well as the brown category was a protective factor for functional disability. By uniting browns and blacks (blacks), the highest chance of self-reporting blacks with the worst health status and the lowest chance of functional disability was maintained. ${ }^{31}$

The majority of the elderly people interviewed were from other municipalities in the state of Amazonas (47.4\%). These results are similar to the study by Oliveira et al. ${ }^{32}$ that evaluating edentulism in the elderly people of Manaus, found that most were born in Manaus, followed by those from other municipalities in the Amazon. According to Silver ${ }^{33}$ the precarious financial situation was the main reason for people to migrate still young to large urban centres or other more developed places. In the elderly group studied, the reasons, possibly, are related to the search for better conditions of care in health, education and possibility of employability.

With regard to marital status, there was a predominance of widowed elderly people $(41.0 \%)$, followed by married people $(29.5 \%)$. This fact is also found in a study by Chaves ${ }^{17}$ with elderly people participants of the Pastoral do Idoso in the neighbourhood of Petrópolis where there was a higher percentage of widows. In the study by Campos et al..$^{34}$ conducted with elderly Brazilian octogenarians, most of them were widows (53.4\%) and Cauduro et al..$^{35}$ also found a high number of widowed women $(43.4 \%)$ in their work with elderly people in Manaus. In Brazil, the 2010 Census showed that $51.0 \%$ of the population were women, increasing the expectation, 78.8 years for women, and 71.6 years for men. ${ }^{36}$ All these phenomena affect the size and configuration of families and reinforces the need to invest in studies that can better understand how women longevity behaves beyond the number of years added to women. ${ }^{30}$

The elderly women live longer than elderly men in most countries, and as a result tend to live with their children or alone, among the various hypotheses that explain their greater experience include differences in exposure to risks, tobacco and alcohol consumption and in attitude towards diseases and medical-obstetric care that reduced the number of maternal deaths. ${ }^{37}$ In the evaluated elderly group, the proportion of elderly women is much higher than that of elderly men. It is believed that men seek less this type of participation in Living Center due to the difficulty in adapting more easily to leisure activities, sports, among other services offered.

Although Manacapuru has a higher number of evangelical churches, the elderly people mostly declared themselves Catholic (76.9\%), with the church being the place they attended most after the Living Center, which meets the results of other studies in the Amazon such as Trindade e Castro ${ }^{38}$ in the city of Parintins (79.6\%) and Cauduro et al. ${ }^{39}$ analyzing the religiosity and spirituality in ageing, and by Cauduro et al. ${ }^{35}(72.4 \%)$. According to Abdala et al. ${ }^{40}$ women are more open to show their religious feelings, participate and get involved in church activities. Research shows that belonging to and valuing religion represents an important support mechanism for the elderly people to face their problems, contributing to greater satisfaction with life and less feeling of helplessness and hopelessness. ${ }^{41}$ Religion has a central dimension in the lives of most elderly people, representing an important source of emotional support influencing physical and mental health, where having a religion seems to contribute decisively to well-being in old age, especially in elderly people with more impoverished social strata. ${ }^{42}$

With reference to the number of children, a greater number of elderly people had between 4 and 6 children. Studies report that the greater the number of children, the greater the chance of the elderly people living with one of them in the third age to receive some type of family support. ${ }^{37}$ In Brazil, the birth rate has currently decreased and the tendency is that future elderly women live alone and without an adequate welfare system to support them when they become dependent. ${ }^{37}$ Research by Campos et al. ${ }^{43}$ showed that divorced elderly people without children living alone have the worst family functioning, even presenting independence for ADLs and IADLs, and that this probably happens due to the absence of family members or a support network, which makes them have to be enough themselves in their care and in their daily life. Similarly, research by Pinheiro et al ${ }^{44}$ on institutionalization of the elderly people showed that the variables: illiterate, single, black and mixed-race, not retired, without health insurance, without children, was associated with the institutionalization of long stay.

Just as for the dimension occupation it is noted that a large percentage of elderly people was retired $(78.2 \%)$. Similar percentages were found by Sampaio26 (82.2\%) in an area covered by the Basic Health Unit in the municipality of Jequié (BA) and Victor et $a .^{45}$ $(60.2 \%)$ in a Basic Family Health Unit in the city of Fortaleza (CE). The economic situation plays a fundamental role in determining health conditions, especially in elderly individuals, who are more vulnerable to the onset of diseases and, consequently, to high financial expenditure on medication, hence the importance of retirement in the 
lives of the elderly people, where for many it is the main source of income. $^{46}$

Retirement represents a permanent income for individuals until death and constitutes a need for individual security in the current era. Initially, for many elderly people, retirement is synonymous with rest; however, after some time, the withdrawal from the life of competition, with the end of the years of work, may generate a crisis in the individual due to reduced self- esteem and the feeling of being useless. ${ }^{47}$ It is believed that in the group studied the majority live from their retirement, constituting for many their only source of income for their livelihood and their family. The fact of retiring also stimulates the search for coexistence centres in order not to feel isolated, as well as others look for other forms of occupation to complement the low value of retirement.

It was verified in the studied group that the majority, $73.1 \%$ of elderly people had monthly income that goes from one to three minimum wages, probably coming from retirements and pension. This finding is in agreement with that reported by Chaves ${ }^{17}$ in the Pastoral do Idoso $(68.0 \%)$ and Bonifácio ${ }^{18}$ in the Centro de Atenção Integral da Melhor Idade (CAIMI) Dr. Paulo Lima (72.0\%), both in the city of Manaus (AM), and by Santos et al. ${ }^{48}$ in the city of João Pessoa (PB) (75.8\%). In Brazilian society, income inequality is a striking characteristic, and is also found among the elderly people. For the vast majority of the Brazilian elderly, the amounts received as retirement do not cover their expenses, especially when the elderly people are the breadwinner of the family group, as in many cases they need to continue to work even if retired ${ }^{49}$ or become indebted to meet their financial needs and those of their dependents. Thus, financial hypo sufficiency ends up compromising the acquisition of medicines, food and even harming the health and quality of life of the elderly people.

In the group studied it was observed that despite the low purchasing power many elderlies had their own house (88.5\%) and of masonry $(75.6 \%)$, and these households had all the basic conditions of sanitation, although Manacapuru has many neighborhoods with a population lacking basic services in housing. Similarities were found in the work of Nunes et al..$^{50}$ in Goiânia (88.7\%); Pereira et al. ${ }^{46}(83.9 \%)$, also showing that on some occasions the housing of the elderly people is a support for other family members and even neighbors. Basic sanitation services in the houses of the elderly people are essential, facilitating the performance of activities of daily life, because where there is no availability of piped water, for example, people need to carry water over long distances, a situation that would become more difficult for an elderly person and could compromise their health.

In relation to the evaluation of functional capacity, the elderly people in this study were mostly (94.6\%) independent to perform their Activities of Daily Life (ADLs). The findings were very similar to those of Barbosa et al. ${ }^{3}$ (61.9\%) in Montes Claros (MG) and higher than those of Batalha ${ }^{51}$ in Manaus (AM). However, a study by Alves ${ }^{52}$ found a higher percentage of dependent elderly people in the activities of daily living (17.2\%) in the municipality of Coari, Amazonas, with a the predominance of instrumental activities $(61.9 \%)$, an association was also identified for falls and ADLs and cognitive function for IADLs. Functional capacity tends to decline with advancing age and, even with healthy ageing, it is expected that the individual from 80 years of age on, they have some degree of physiological impairment to perform the Activities of Daily Life (ADLs), and the intensity and frequency of this impairment depend on the general health and living conditions over the years. ${ }^{7}$ The greater the difficulties of the individual in performing the ADLs, the more severe is the degree of disability, whereas the IADLs that includes more adaptive or necessary tasks for community life are, are considered more difficult and complex tasks than the ADLs. ${ }^{53}$

With respect to the functional capacity evaluation functions of the elderly people in this study, the greatest emphasis is on general urinary incontinence $(28.2 \%)$ and for women $(33.8 \%)$, as found in other studies Barbosa et al. ${ }^{3}$ (9.4\%) and Carneiro et al..$^{54}(31.1 \%)$, among women, and higher than that found by Kessler et al. ${ }^{55}(20.7 \%)$ in Bagé (RS). They report that the prevalence of urinary incontinence in the elderly people is associated with factors such as gender, skin colour, low education, cognitive deficit, walking with help, report of falls, and negative self-perception of health, arthritis/arthrosis/ rheumatism and fragility.

Urinary incontinence is one of the major geriatric syndromes, and is often not identified due to lack of reports from the elderly people, who feel embarrassed and only refer to this situation when they are asked. ${ }^{56}$ In addition, urinary incontinence predisposes the individual to genitourinary infections and contributes to a greater institutionalization of the elderly people, and lack of sphincter control can lead to social isolation, changes in self-esteem and self-image, impairing their quality of life and well-being. ${ }^{56}$

Functional disability is a phenomenon that occurs differently between men and women and, although the incidence of disability is similar in both sexes, usually, women are the most affected by disability. ${ }^{57}$ The decline in functional capacity increases with age and, as the individual ages, many daily tasks, however simple they may be, become difficult to perform, often being imperceptible for a long time until the individual realizes his or her dependence since it requires another person to perform it. ${ }^{58}$ The maintenance of functional capacity is one of the important indicators of successful ageing and quality of life of the elderly people. The results of this study revealed in general that most elderly people are able to perform all daily activities without needing help.

About the IADLs of this study, it was seen the elderly people had greater dependence to perform them $(56.0 \%)$. Data from the study by Nunes et al. ${ }^{50}$ also show these results, showing that most of the elderly were partially dependent to perform the instrumental activities of daily living $(45.7 \%)$. As well as the study by Barbosa et al. ${ }^{3}$ which found greater dependence, especially to: go somewhere alone, use the telephone, wash and iron. The commitment to perform daily IADLs that are more complex than ADLs can harm the social life of the elderly people and promote a disorder for their family, where depending on the activity involved, will have to provide time, energy and financial resources to meet the existing demands ${ }^{7}$. Hierarchically, the losses occur from instrumental activities of daily living to Activities of Daily Life (ADLs), ${ }^{59}$ due to the IADLs require greater physical and cognitive integrity compared to the ADLs. ${ }^{60,61}$ The greater dependence on IADLs in the group of elderly people in this study was related to the use of telephone, followed by help to: visit distant places, perform domestic manual work and take the medication at the right dose and time. Concerning the IADLs that perform with independence have a higher percentage: taking care of finances $(94.9 \%)$ and shopping $(91.0 \%)$

Studies showed that certain disabilities may be associated with the lack of education of the elderly people, such as: handling money, taking medication, shopping and using means of transportation. For the elderly people, these disabilities compromise socialization by reducing their autonomy, making it necessary to provide conditions that favor access to knowledge and resources in such a way that they become autonomous and independent. ${ }^{7}$ In addition to low education, 
the elderly with low vision have difficulty in using the telephone, preparing meals, manual labour, washing and ironing clothes and taking medication correctly. ${ }^{62}$ In the evaluated group, it was observed that most of the elderly people had a preserved functional capacity, meaning an acceptable level of functional health, because the ADLs and IADLs are complex activities for the elderly people, especially for those who have some degree of impairment of health, impairing their autonomy and independence, as well as can prevent the elderly people from enjoying and using their free time, develop new skills and potential.

\section{Closing remarks}

From the analysis performed it was possible to determine the profile of the group of elderly participants at the Eliza Queiroz Maciel Living Center of Manacapuru, Amazonas, whose results allowed the following considerations: respecting sociodemographic and economic factors and housing conditions, the elderly group studied consisted mostly of women, which confirms the feminization of old age, they were young elderly people with low education, brown colour, most from other municipalities in the Amazon, widows, Catholics, with children, retirees, monthly income of 1 to 3 minimum wages, lived in their own house generally of masonry, with basic sanitation.

Regarding the Activities of Daily Life (ADLs), these were performed by the majority of the elderly people, being found greater difficulty in the ADLs on continence, where a small portion reported suffering from occasional urinary incontinence. It is worth mentioning that this health problem can contribute to the hospitalization of the elderly people, in addition to leading to social isolation, hindering their engagement in social groups that offer an old age with a higher quality of life, such as living centres.

In the Instrumental Activities of Daily Life (IADLs), most elderly people found it more difficult to use the telephone, travel to distant places, do domestic manual work, and take medication at the right dose and time. In general, the studied group presents a good maintenance of the functional capacity, with preservation of its autonomy and independence, being able to fill its free time with pleasure, satisfaction and social contacts. In this way, quality of life is not the absence of diseases, but rather an ageing in a healthy way, with preservation of its autonomy and independence even in the presence of morbidities And for a healthy ageing, it is necessary that health and social policies promote functional ability and adequate social support for the elderly population. It is also important to emphasize that the major objective in health care should not only be to prolong life, but mainly to maintain the functional capacity of the individual so that he can remain longer with autonomy and independence. Therefore, public policies should work on health promotion and disease prevention to benefit this population segment.

\section{Acknowledgements}

To the elderly people and the manager of the Centro de Convivencia do Idoso (Living Center of the Elderly) Eliza Queiroz Maciel of Manacapuru for the direct contribution to the construction of this work. To Universidade do Estado do Amazonas (UEA) and Fundação de Amparo à Pesquisa do Estado do Amazonas (FAPEAM).

\section{Funding details}

None.

\section{Conflict of interest}

The authors declare there is no conflict of interest.

\section{References}

1. Camarano AA. New demographic regime: a new relationship between population and development? Brasília: Ipea; Rio de Janeiro; 2014.

2. Brasil. Instituto Brasileiro de Geografia e Estatística (IBGE). Projeção da população 2018: número de habitantes do país deve parar de crescer em 2047. Agência de Notícias. Brasília, maio de. 2019.

3. Barbosa BR, Almeida JM de, Barbosa MR, et al. Assessment of functional capacity of the elderly and factors associated with disability. Ciênc saúde coletiva. 2014;19(8):3317-3325.

4. Ricci NA, Kubota MT, Cordeiro RC. Agreement of observations on the functional capacity of elderly in home care. Rev Saúde Pública. 2005;39(4):655-662.

5. Gordilho A. Desafios a serem enfrentados no terceiro milênio pelo setor saúde na atenção integral ao idoso. Envelhecimento humano, UNATI, Rio de Janeiro: UERJ; 2000

6. Alves LC, Leite IC, Machado CJ. Conceptualizing and measuring the functional disability of the elderly population: a literature review. Cienc Saúde Colet. 2008;13(4):1199-1207.

7. Costa EC, Nakatani AYK, Bachion MM. Ability of the community's elderly to develop daily living activities and instrumental daily living activities. Acta Paulista de Enfermagem. 2006;19(1):43-48.

8. Rosa TEC, Rita CL Ribeiro, Lina EFPL Rosado, et al. Fatores determinantes da capacidade funcional entre idosos. Revista Saúde Pública. 2003;37(1):40-48.

9. Abreu FMC, Rodrigo Gomes, Andrea Carmen, et al. Autonomy profile of a group of institutionalized elderly. Brazilian Forum of Physical Education and Sport Sciences. Revista Mineira de Educação Física. 2002;10:455.

10. Tavares DMS, Gilberto de Araújo, Helena Hemiko, et al. Incapacidade Funcional entre idosos residentes em município do interior de Minas Gerais. Texto Contexto Enfermagem. 2007;1(1):32-39.

11. Guimarães LHCT, Débora CA Galdino, Fábio Luiz Mendonça, et al. Evaluation of functional capacity of elderly in physical therapy treatment. Revista Neurociências. 2004;12(3):130-133.

12. Pereira RJ. Contribution of the physical, social, psychological and environmental domains to the overall quality of life of the elderly. Revista psiquiátrica do Rio Grande do Sul. 2006;28(1):27-38.

13. Gil AC. Métodos e técnicas de pesquisa social. São Paulo: Atlas, 2006. p. $1-220$.

14. Katz S, Ford AB, Moskowitz RW, et al. Studies of illness in the aged. The index of ADL: a standardized measure of biological and psychosocial function. JAMA. 1963;185:914-919.

15. Lawton MP, Brody EM. Assessment of older people: self-maintaining and instrumental activities of daily living. Gerontologist. 1969;9(3):179186.

16. Brasil. Ministério da Saúde. Secretaria de Atenção à Saúde. Departamento de Atenção Básica. Envelhecimento e saúde da pessoa idosa. Brasília: MS. 2006

17. Chaves SS. Avaliação da Saúde geral de idosos participantes da pastoral do idoso no bairro de Petrópolis em Manaus (AM). Manaus. Universidade do Estado do Amazonas, Manaus; 2008.

18. Bonifácio FA. Situação nutricional de idosos usuários do Centro de Atenção Integral da Melhor Idade (CAIMI) Dr. Paulo Lima em Manaus $(A M)$. [Monografia]: Manaus, Universidade do Estado do Amazonas. 2008.

19. Kumpel DA, Adriana de Camargo, Dalva Maria Pomatti, et al. Obesity in the elderly followed by the family health strategy. Texto contexto enfermagem. 2011;20 (3):471-477. 
20. Reis LA, Gilson de Vasconcelos, Thaiza Teixeira, et al. Perception of family support in low-income elderly and associated factors. Texto contexto enfermagem. 2011;20:52-58.

21. Camarano AA. Mulher idosa: suporte familiar ou agente de mudança? Estud av on line. 2003;17(49):35-63.

22. Nasri F. O envelhecimento populacional no Brasil. Einstein. 2008;6(1):4-6.

23. Hurtado-Guerrero AF, Alencar FH, Hurtado-Guerrero JC. Occurrence of enteroparasites in the geron population of Nova Olinda do Norte, Amazonas-Brazil. Acta Amazônica. 2005;35(4):487-490.

24. Mazo GZ, Liposcki DB, Ananda C, et al. Health conditions, incidence of falls and physical activity level of the elderly. Revista brasileira de fisioterapia. 2007;1(6):437-442.

25. Mazzo GZ, Lopes MA, Benedetti TB. Atividade fisica e o idoso: concepção gerontológica. $2^{\text {nd }} \mathrm{ed}$. Porto Alegre: Sulina; 2004.

26. Sampaio LS. Sociodemographic and health conditions of elderly residents at home in the city of Jequié- BA. Revista brasileira de Geriatria e Gerontologia. 2009;12(2):267-274.

27. Feliciano AB, Moraes AS, Freitas ICM. The profile of low-income elderly in the city of São Carlos, São Paulo, Brazil: an epidemiological study. Caderno de Saúde Pública. 2004;20(6):1575-1585.

28. Portela CS. Perfil epidemiológico dos idosos atendidos no centro de Atenção Integral à Melhor Idade (CAIMI) Rodrigues Viana, Manaus $(A M)$. [Monografia]: Manaus. Universidade do Estado do Amazonas; 2009

29. Souza AI, Silver LD. Sociodemographic profile and self-reported health status among elderly women in a low-income locality. Escola Anna Nery Revista Enfermagem. 2008;12(4):706-716.

30. Brasil. Instituto Brasileiro de Geografia e Estatística (IBGE). Primeiros resultados do censo 2010. Rio de Janeiro. 2010.

31. Oliveira BLCAl de, Thomaz EBAF, Silva RA da. Association of color / race with health indicators for the elderly in Brazil: a study based on the National Household Sample Survey (2008). Cad Saúde Pública. 2014;30(7):1438-1452.

32. Oliveira GM. Alterações no Consumo Alimentar Decorrentes da Perda Dentária dos Idosos do Clube da Terceira Idade Anos Dourados Japiim II - Manaus, AM. VIII Congresso Brasileiro de Epidemiologia. São Paulo; 12 a 16 novembro de 2011 .

33. Souza AI, Silver LD. Sociodemographic profile and self-reported health status among elderly women in a low-income locality. Escola Anna Nery Revista Enfermagem. 2008;12(4):706-716.

34. Campos ACV, Efigênia Ferreira, Andréa Maria Duarte, et al. Profile of healthy aging in Brazilian octogenarian elderly. Rev Latino-Am Enfermagem. 2016;24:e2724.

35. Cauduro MHF, Adroaldo Cauduro, Antônio Carlos, et al. Living and health conditions of the elderly in Manaus and Porto Alegre - Electronic data. Porto Alegre: EDIPUCRS. 2011;1-85.

36. Brasil. Instituto Brasileiro de Geografia e Estatística (IBGE). Coordenação de População e Indicadores Sociais. Estatísticas de gênero: uma análise dos resultados do Censo Demográfico 2010. Rio de Janeiro: IBGE, 2014.

37. Veras R, Marcelo Alves, Tereza Cristina, et al. Old age with a healthy future perspective. Organização Renato Peixoto Veras. Rio de janeiro: UERJ, UnATI. 2001;1-145.

38. Trindade FM, Castro FF. Condições de saúde do idoso de uma Unidade Básica de Saúde de Parintins, Amazonas. Universidade do Estado do Amazonas, (Monografia), Ciências da Saúde. 2016.
39. Cauduro A. Religiosidade e espiritualidade. In: Terra NL et al., editor Envelhecimento e suas múltiplas áreas do conhecimento. Porto Alegre: EDIPUCRS. 2010

40. Abdala GA, Miako Kimura, Yeda Aparecida, et al. Religiosity and healthrelated quality of life of the elderly. Rev Saúde Pública. 2015;49:55.

41. Duarte YAO. Religiosity and Aging: an analysis of the profile of the elderly in the city of São Paulo. Saúde Coletiva. 2008;5(24):173-177

42. Floriano PJ, Dalgalarrondo P. Mental health, quality of life and religion in older adults in a family health program. Jornal Brasileiro Psiquiátrico. 2007;56(3):162-170.

43. Campos ACV, Gabrielli Pinho, Efigênia Ferreira, et al. Family functionality of elderly community-dwelling Brazilians. Acta paul enferm. 2017;30(4):358-367.

44. Pinheiro NCG. Inequality in the profile of institutionalized elderly in Natal, Brazil. Ciênc saúde coletiva. 2016;21(11):3399-3405.

45. Victor JF, Ximenes, Lorena, Almeida, Paulo, et al. Sociodemographic and clinical profile of elderly assisted at a Family Health Basic Unit. Acta Paulista de Enfermagem. 2009;22(1):49-54.

46. Pereira RJ. Análise do perfil sociossanitário de idosos: a importância do Programa de Saúde da Família. Revista Medica de Minas Gerais. 2010;20(1):5-15.

47. Mendes RSSB, Gusmao, Josiane, Faro, Ana, et al. The social situation of the elderly in Brazil: a brief consideration. Acta Paul Enfermagem. $2005 ; 18(4): 422-426$.

48. Santos SR, Iolanda Beserra da, Henriques, et al. Quality of life of the elderly in the community: application of the Flanagan Scale. Revista Latino-Am Enfermagem. 2002;10(6):757-764.

49. Bulla LC, Kaefer CO. Trabalho e aposentadoria: as repercussões sociais na vida do idoso aposentado. Revista Virtual Textos \& Contextos. 2003;2.

50. Nunes DP, Adélia Yaeko, Érika Aparecida, et al. Functional capacity, socioeconomic and health conditions of the elderly attended by Family Health teams of Goiânia. Ciências saúde coletiva. 2010;15(6):28872898 .

51. Batalha CA. Avaliação da capacidade funcional dos idosos da área de abrangência da Unidade Básica de Saúde (UBS) SO46 da Estratégia de Saúde da Família (ESF) do bairro São Francisco em Manaus (AM). [Monografia]: Manaus. Universidade do Estado do Amazonas; 2009.

52. Alves EG. Capacidade funcional de idosos do município de Coari, Amazonas. Manaus. Universidade Federal do Amazonas; 2016.

53. Alves LC, Beatriz Consuelo Quinet, Maria Estrella López, et al. The influence of chronic diseases on the functional capacity of the elderly in the city of São Paulo. Caderno de Saúde pública. 2007;23(8):1924 1930 .

54. Carneiro JA. Prevalência e fatores associados à incontinência urinária em idosos não institucionalizados. Cad saúde colet. 2017;25(3):268277.

55. Kessler M, Luiz Augusto Facchini, Mariangela Uhlmann, et al. Prevalence of urinary incontinence in the elderly and relationship with physical and mental health indicators. Rev Bras Geriatria e Gerontol. 2018;21(4):409-419.

56. Veras RP, Célia Pereira Caldas, Flávia Dantas Coelho, et al. Promoting Health and Preventing Addiction: Identifying Frailty Indicators in Independent Elderly, Frailty Indicators in the Elderly. Revista Brasileira Geriátrica e Gerontologia. 2007;10(3):355-370.

57. Giacomin KC, Sérgio V Peixoto, Elizabeth Uchoa, et al. Populationbased study of factors associated with functional disability among the elderly in the metropolitan region of Belo Horizonte, Minas Gerais, Brazil. Caderno de Saúde Pública. 2008;24(6):1260-1270. 
58. Araújo MOPH, Ceolim MF. Evaluation of the degree of independence of elderly residents in long-term care institutions. Revista Escola Enfermagem - USP. 2007;41(3):378-385.

59. Santos AA dos, Pavarini SCI. Functionality of elderly with cognitive impairment in different contexts of social vulnerability. Acta paul enferm. 2011;24(4):520-526.

60. Millán-Calenti JC, Javier Tubío, Salvador Pita, et al. Prevalence of functional disability in activities of daily living (ADL), instrumental activities of daily living (IADL) and associated factors, as predictors of morbidity and mortality. Arch Gerontol Geriatr. 2010;50(3):306-310.
61. Freitas RS. Functional capacity and associated factors in the elderly: population study. Acta paul. enferm. 2012;25(6):933-939.

62. Borges SM, Cintra FA. Relationship between visual acuity and instrumental activities of daily living in outpatients. Revista Brasileira de oftalmologia. 2010;69(3):46-151. 